Jurnal Agri Sains, Vol. 5 No. 1, (Juni 2021)

\title{
ANALISIS RISIKO USAHATANI KELAPA SAWIT \\ DI KECAMATAN LIMBUR LUBUK MENGKUANG KABUPATEN BUNGO
}

\section{RISK ANALYSIS OF OIL PALM BUSINESS IN THE \\ DISTRICT OF LIMBUR LUBUK MENGKUANG BUNGO DISTRICT}

\author{
Asminar, Riki, Widuri Susilawati \\ Program Studi Agribisnis, Fakultas Pertanian, Universitas Muara Bungo, Jl. Pendidikan, \\ RT. 10 RW. 02 No. 10 Kelurahan Sungai Binjai. Kecamatan Bathin III. Kabupaten \\ Bungo, Jambi 37228, Indonesia \\ asminarjabir@yahoo.com
}

\begin{abstract}
ABSTRAK
Kelapa sawit komoditi perkebunan unggulan dan utama Indonesia, sebagai penyumbang devisa terbesar dengan komoditi lainnya. Tujuan penelitian untuk mengetahui besarnya risiko produksi, risiko pendapatan dan memitigasi risiko di Kecamatan limbur Lubuk Mengkuang Kabupaten Bungo dengan menggunakan metode survei. Metode analisis data menggunakan koefisiensi variasi, dan analisis deskriptif.

Hasil penelitian menunjukan bahwa risiko diperoleh dari nilai koefisien variasi (CV) sebesar 0,0024 artinya apabila $\mathrm{CV}<0,5$ maka risiko usaha tani yang dihadapi petani rendah. Risiko pendapatan diperoleh dari nilai koefisien variasi (CV) sebesar 0,00062 artinya apabila $\mathrm{CV}<0.5$ maka risiko pendapatan yang dihadapi petani Rendah. Upaya memitigasi risiko produksi dan pendapatan adalah, mempersiapkan obat obatan yang sesuai untuk mengatasi hama dan penyakit tersebut, ketua kelompok petani menyusun RDKK (recana definitive kebutuhan kelompok) dengan sesuai data petani yang ada, membuat jalan swadaya kerja sama antara kelompok tani dan pemerintah, RDKK di awasi dari proses pengajuan sampai akhir agar tidak ada pihak yang menyalah gunakan pupuk bersubsidi, Risiko pendapatan (a) bagi petani hendak nya memperhatikan sumber daya peralatan yang digunakan dalam berusahtani dengan menambah peralatan yang masih kurang sehingga mampu meningkatkan produksi dalam usaha tani kelapasawit(b)bagi petani sebaiknya memperhatikan persedian pasar untuk penjualan hasil produksi kelapa sawit TBS yaitu perusahaan yang bermitra dengan memperkuat kelembagaan petani sehingga mampu menjual hasil produksi tepat waktu.
\end{abstract}

Kata Kunci: Risiko Produksi, Risiko Pendapatan, Memitigasi Risiko

\section{ABSTRACT}

Palm oil is Indonesia's leading and main plantation commodity, as the largest foreign exchange earner with other commodities. The purpose of the study was to determine the magnitude of production risk, income risk and mitigate risk in Limbur District, Lubuk Mengkuang, Bungo Regency by using a survey method. Methods of data analysis using the coefficient of variation, and descriptive analysis.

The results showed that the risk obtained from the coefficient of variation (CV) of 0.0024 means that if the $C V<0.5$ then the risk of farming faced by farmers is low. Income risk is obtained from the coefficient of variation $(C V)$ of 0.00062 , meaning that if $C V<0.5$ then the income risk faced by farmers is low. Efforts to mitigate production and income risks 
are, preparing appropriate medicines to overcome these pests and diseases, the head of the farmer group preparing the RDKK (definitive plan for group needs) in accordance with existing farmer data, making a self-help way of cooperation between farmer groups and the government, RDKK supervised from the submission process to the end so that no party misuses subsidized fertilizers, Income risk (a) for farmers should pay attention to the equipment resources used in farming by adding equipment that is still lacking so as to increase production in oil palm farming ( $b$ For farmers, it is better to pay attention to market supply for the sale of FFB oil palm products, namely companies that partner with farmers to strengthen institutions so that they are able to sell their products on time.

Keywords: Production Risk, Income Risk, Mitigating Risk

\section{Pendahuluan}

Komoditi dari subsektor perkebunan yang mempunyai peran cukup penting dalam kegiatan perekonomian di Indonesia adalah kelapa sawit. Kelapa sawit merupakan komoditas perkebunan unggulan dan utama Indonesia. Tanaman yang produk utamanya terdiri dari minyak sawit mentah (Crude Palm Oil atau CPO) dan minyak inti sawit (Palm Kernel Oil atau $P K O$ ) ini memiliki nilai ekonomis yang tinggi dan menjadi salah satu penyumbang devisa negara yang terbesar dibandingkan dengan komoditas perkebunan lainnya. Hingga saat ini kelapa sawit telah diusahakan dalam bentuk perkebunan dan pabrik pengolahan kelapa sawit hingga menjadi minyak dan produk turunannya. Indonesia merupakan negara produsen dan eksportir kelapa sawit terbesar di dunia (Effendi, 2011). Suatu hal yang sangatlah tepat jika ingin memperbaiki tatanan ekonomi yang ada di negara-negara yang memiliki daerah pertanian yang luas adalah dengan membangun daerah tersebut yang nantinya pasti akan ikut berperan serta dalam memperbaiki struktur tatanan ekonomi di negara yang bersangkutan (Fikriman, 2017).

Komoditi unggulan di Provinsi Jambi di sektor perkebunan adalah komoditi kelapa sawit. saat ini ini Jambi memproduksi kelapa sawit hanya sampai bahan setengah jadi seperti CPO (Crude Palm Oil). Kelapa Sawit merupaka suatu komoditas unggulan di Provinsi Jmabi dan produktivitas bisa dipengaruh dari dalam perkebunan sawit itu sendiri seperti faktor kerja serta faktor luar perkebunan sawit itu sendiri (Fikriman dan Herdiansyah. 2017). Luas area dan produksi sawit di Provinsi Jambi berfluktuasi luas lahan terbesar pada Tahaun 2019 dengan luas area 931.970(Ha) dengan produksi 2.202.545(Ton) sedang untuk luas lahan danproduksi terkecil pada Tahun 2017 luas area 887.795(Ha) dengan produksi 1.849.969 (Ton). Provinsi Jambi yang berpontensi untuk di Kabupaten untuk kelapa sawit adalah Kabupaten Bungo merupakan kabupaten yang memiliki pontensi dalam bidang perkebunan terutama dalam sektor kelapa sawit dimana sampai saat ini ini sangat menjadi perhatian besar oleh pemerintah maupun masyarakat untuk membudidayakan kelapa sawit. Selengkapanya luas area dan produksi tanaman kelapa sawit dapat dilihat di table di bawah

Tabel 1. Luas Areal dan Produksi Kelapa Sawit Di Kabupaten Bungo Tahun 2015-2019.

\begin{tabular}{cccc}
\hline No & Tahun & $\begin{array}{c}\text { Luas } \\
\text { area } \\
\text { (Ha) }\end{array}$ & $\begin{array}{c}\text { Produksi } \\
\text { (Ton) }\end{array}$ \\
\hline 1 & 2015 & 53.847 & 103.382 \\
2 & 2016 & 64.832 & 112.726 \\
3 & 2017 & 56.045 & 103.424 \\
4 & 2018 & 60.265 & 115.222 \\
5 & 2019 & 98.460 & 115.461 \\
\hline
\end{tabular}

Sumber Data: Badan Pusat Stastistik (2019)

Tabel 1 menunjukkan bahwa luas area dan produksi kelapa sawit di Kabupaten Bungo berfluktuasi luas lahan dan produksi tebesar pada tahun 2019 
dengan luas area 98.460 (Ha) dengan produksi 115.461 (Ton) untuk luas lahan dan produksi yang terkecil pada tahun 2015 luas area 53.847 (Ha) dengan produksi 103.382(Ton). Hal ini menunjukan bahwa di Kabupaten Bungo kelapa sawit menjadi sangat berpotensi untuk dikembang-kan. Berdasarkan data Badan Pusat Statistik (2019), luas area dan produksi kelapa sawit Perkecamatan di Kabupaten Bungo menunju-kan bahwa, untuk Kecamatan produksi tertinggi yaitu Kecamatan Pelepat 19. 464 (Ton) dengan luas area $17.798 \quad(\mathrm{Ha})$, sedangkan kecamatan yang terendah yaitu Kecamatan Pasar Muara Bungo memiliki luas area 16 (Ha) dengan produksi 33 (Ton) di Tahun 2019. Dari perkembangan luas areal dan Produksi Kelapa Sawit menunjukan Masyarakat masih tertarik dalam mengelola sektor perkebunan Kelapa sawiti karena selain mudah dalam penanaman dan perawatan serta menjanjikan pendapatan yang tinggi, kelapa sawit juga sangat diperlukan dalam berbagai industri sehinga petani tidak perlu khawatir terhadap pemasarannya.

Kecamatan Limbur Lubuk Mengku-ang banyak memiliki perusahaan di bidang kelapa sawit dan pabrik kelapa sawit, koperasi kelapa sawit di Limbur Lubuk Mengkuang memiliki ke istimewaan tersendiri dari pada kecamatan lain setiap perusahaan yang ada di Lingkungan Limbur Lubuk Mengkuang akan memberikan kebun plasma untuk masyarakat atau (KKPA) sistim kredit koperasi primer anggota Kecamatan Limbur Lubuk Mengkuang. Kecamatan Limbur Lubuk Mengkuang memiliki luas area $11.954(\mathrm{Ha})$ dan produksi 15.401.316 (Kg) dari 4.006 petani, dengan jumlah produksi Desa Sekar Mengkuang merupakan desa yang memiliki produksi kelapa sawit yang tertinggi di Kecamatan Limbur Lubuk Mengkuang yaitu 2.967.920 (Kg) dengan luas lahan 1.073 (Ha) memiliki jumlah pertani 366 orang sedangkan desa Baru Lubuk Mengkuang merupakan desa produksi terendah yaitu
$61.000(\mathrm{Kg})$ dengan luas lahan $147(\mathrm{Ha})$ Petani 35 orang. Berdasarkan data-data di atas menunjukan bahwa Saat ini masyarakat di Kecamatan Limbur Lubuk Mengkuang lebih memilih kelapa sawit sebagai tanaman utama. Faktor menarik lainnya adalah tanaman ini cepat berbuah dalam waktu 3 tahun. Oleh karena itu Kecamatan Limbur Lubuk Mengkuang mengandalkan komoditi ini untuk mensejah-terakan petani dan untuk pertumbuhan ekonomi wilayah tersebut.

Kegiatan pada sektor pertanian yang menyangkut proses produksi selalu dihadap-kan dengan situasi risiko (risk) dan ketidakpastian (uncertainty). Pada risiko peluang terjadinya kemungkinan merugi dapat diketahui terlebih dahulu, sedangkan ketidakpastian merupakan sesuatu yang tidak bisa diramalkan sebelumnya karena peluang terjadinya merugi belum diketahui.Sumber ketidakpastian yang penting di sektor pertanian adalah fluktuasi hasil pertanian dan fluktuasi harga. Ketidakpastian hasil pertanian disebabkan oleh faktor alam seperti iklim, hama dan penyakit serta kekeringan. Jadi produksi menjadi gagal dan berpengaruh terhadap keputusan petani untuk berusahatani berikutnya (Soekartawi, 1993)

Adapun tujuan penelitian ini adalah untuk mengetahui besarnya Risiko Produksi dan pendapatan serta mengidentifikasi upaya-upaya yang perlu dilakukan oleh Petani Kelapa Sawit di Kecamatan Limbur Lubuk Mengkuang dalam memitigasi Risiko Produksi dan Pendapatan. sehingga penulis tertarik untuk meneliti lebih mendalam tentang Analisis Risiko UsahaTani kelapa sawit di Kecamatan Limbur Lubuk Mengkuang Kabupaten Bungo.yang memiliki peluang untuk menjadi sektor potensial yang dapat mempengaruhi pendapatan dan Produksi dalam bentuk penelitian dengan judul “ Analisis Risiko Usaha Tani Kelapa Sawit di Kecamatan Limbur Lubuk Mengkuang." 
Metode Penelitian

Penelitian ini dilakukan di Kecamatan Limbur Lubuk Mengkuang Kabupaten Bungo Provinsi Jambi. Pemilihan lokasi dilakukan secara sengaja, dengan pertimbangan bahwa Kecamatan Limbur Lubuk Mengkuang memiliki luas lahan 11.715 (Ha) dengan produksi 16.447 (Ton) dan masyarakat menjual hasil kelapa sawitnya ke koperasi unit desa, koperasi yang masih aktif di setiap desa dan kerja sama antara koperasi dengan petani (Kantor ke Kacamatan Limbut Lubuk Mengkuang 2019) Penelitian ini dilaksanakan pada 1 Mei sampai dengan 1 Juli 2020.

Jenis data yang digunakan dalam penelitian ini adalah data primer diperoleh dari hasil wawancara dengan responden menggunakan kuisioner yaitu petani (anggota kelompok tani). Responden dalam penelitian ini difokuskan pada petani kelapa sawit. Dan data sekunder yaitu data yang diperoleh dari internet, hasil penelitian-penilitian terdahulu dan literatur pada bagian lembaga atau instansi terkaik

Penelitian ini merupakan jenis survey. Penelitian survey dapat memastikan berpa besar pengaruh yang disebabkan oleh satu variabel dalam hubungan dengan variasi yang disebabkan oleh variabel lain. Pendeka-tan penelitian kuantitatif. Data kuantitatif dilakukan dengan metode survey, yaitu koe-sioner instrument utama untuk penelitian. Data yang digunakan dalam peneltian ini adalah data kuantitatif yang di dukung oleh data kualitatif.

Dalam penelitian ini pengambilan sampel desa menggunakan metode purposive sampling yaitu dipilih desa dengan jumlah produksi 3 besar di Kecamatan Limbur Lubuk Mengkuang yaitu : Desa Limbur Baru, Desa Sekar Mengkuang dan Desa Rantau Tipu

Pengambilan sampel petani menggu-nakan metode simple random sampling sebagai berikut:
Tabel 2. Desa Sampel

\begin{tabular}{clcc}
\hline No & \multicolumn{1}{c}{ Desa } & Petani & Sampel(10\%) \\
\hline 1 & Limbur & 392 & 39 \\
2 & Baru & 366 & 37 \\
3 & Sekar & 760 & 76 \\
& Mengkuang & & \\
& Rantau & & \\
& Tipu & & \\
\hline & Jumlah & 1.518 & 152 \\
\hline
\end{tabular}

Hal ini sesuai dengan pendapat Arikunto (2006) yang menyatakan bahwa apabila subjeknya kurang dari 100, lebih baik diambil semua, sehingga penelitiannya merupakan penelitian populasi.Selanjutnya jika subyeknya besar (lebih dari 100) dapat menggunakan sampel. Menurutnya sampel diambil antara 10\%-15\% hingga 20\%-25\% atau bahkan boleh lebih dari $25 \%$ dari jumlah populasi. Untuk mencapai tujuan penelitian, analisis data yang digunakan dalam penelitian ini yaitu:

1. Untuk mengetahui risiko produksi kelapa sawit di Kecamatan Limbur Lubuk Mengkuang

Rumus cv:

$$
\mathrm{CV}=\frac{\boldsymbol{\sigma}}{\mathbf{Q}}
$$

Keterangans

$\mathrm{CV}$ : Koefisien Variasi

$\sigma:$ Standar Deviasi

Q : Rata-rata Produksi (Kg)

Rumus standar deviasi:

$\sigma=\sqrt{\frac{\sum_{l}^{n}=1\left(\mathrm{x}_{i}-\overline{\mathrm{x}}\right)}{n-1}}$

$\sigma=$ Standar Deviasi/Simpangan Baku

$\mathrm{Xi}=$ Data produksi Satu tahun

$\mathrm{X}=$ Data rata-rata produksi satu bulan

$\mathrm{n}=$ Jumlah sampel

kriteria

C $\mathrm{V} \leq 0,5$ maka risiko produksi usahatani kelapa sawit rendah $\mathrm{C} \mathrm{V}>0.5$ maka risiko produksi usahatani kelapa sawit tinggi

2 Untuk mengetahui besar nya risiko pendapatan yang di hadapi petani 
3 kelapa sawit di kecamatan limbur lubukl menmgkuamg.

- pendapatan ( I=TR-TC)

Keterangan

$\mathrm{I}=$ Pendapatan

$\mathrm{TR}=$ Total penerimaan (total revenue)

$\mathrm{TC}=$ Total biaya $($ total cost $)$

- Biaya produksi (TC=TFC+TVC)

Keterangan

$\mathrm{TC}=$ Total Biaya $(\mathrm{Rp})$

TVC $=$ Total Biaya Variabel $(\mathrm{Rp})$

$\mathrm{TFC}=$ Total Biaya Tetap $(\mathrm{Rp})$

Rumus CV

$\mathrm{cv}=\frac{\boldsymbol{\sigma}}{\mathbf{Y}}$

keterangan

$\mathrm{CV}$ : Koefisien Variasi

$\sigma:$ Standar Deviasi

$\mathrm{y}:$ Pendapatan

Rumus standar deviasi:

$\sigma=\sqrt{\frac{\sum_{l}^{n}=1\left(\mathrm{x}_{i}-\overline{\mathrm{x}}\right)}{n-1}}$

keterangan

$\sigma=$ Standar Deviasi/Simpangan Baku

$\mathrm{Xi}=$ Data /pendapatan

$\overline{\mathrm{x}}=$ Data rata-rata/pendapatan

$\mathrm{n}=$ Jumlah sampel

Kriteria

\begin{tabular}{|c|c|}
\hline $\begin{array}{l}\mathrm{C} V \leq \\
\text { pendapatan } \\
\text { sawit rendah }\end{array}$ & $\begin{array}{l}0,5 \text { maka } \\
\text { usahatani }\end{array}$ \\
\hline $\begin{array}{l}\mathrm{C} \quad \mathrm{V} \quad> \\
\text { pendapatan } \\
\text { sawit tinggi }\end{array}$ & $\begin{array}{l}0.5 \text { maka } \\
\text { usahatani }\end{array}$ \\
\hline
\end{tabular}

Untuk mengidentifikasi upayaupaya yang perlu dilakukan oleh Petani Kelapa Sawit di Kecamatan Limbur Lubuk Meng-kuang dalam memitigasi Risiko Produksi dan Pendapatan (menggunakan analisis deskriptif), yaitu dengan mendeskripsikan upaya-upaya yang perlu dilakukan petani dalam memitigasi risiko yang dihadapi selama melakukan usahatani kelapa sawit. Mitigasi risiko ini dilakukan agar dapat meminimalisir atau mengurangi kerugian yang akan terjadi akibat dari risiko dalam usahatani.

\section{Hasil Dan Pembahasan}

\section{Identitas Petani Responden}

Identitas petani responden menggam-barkan keadaan dan kondisi status petani responden dalam usahataninya. Dengan adanya identitas petani responden maka akan memudahkan dalam menganalisis usaha taninya. Identitas responden meliputi nama responden, umur, tingkat pendidikan, lama berusahatani, jumlah tanggungan keluarga dan luas lahan. Identitas petani responden akan dibahas berikut ini.

Umur akan sangat mempengaruhi dalam kegiatan berusahatani. Hal tersebut berhubungan dengan kemampuan bekerja dan cara berpikir petani dalam menerima inovasi baru. Pada umumnya petani yang berumur muda mempunyai kemampuan fisik lebih kuat dan responsif terhadap penerapan inovasi baru dibandingkan petani yang berumur tua. Hasil penelitian menunjukan bahwa petani responden dominan umur antara 30-40 tahun sebanyak (42,76\%) Petani kelapa sawit di Kecamatan Limbur Lubuk Mengkuang yang bekerja sebagai petani masih tergolong produktif, usia produktif yakni antara 15 - 64 tahun. Hal ini sesuai dengan pendapat Tjiptoherijanto (2001), usia produktif adalah usia dimana seseorang sudah bisa bekerja. Usia produktif itu dimulai pada usia 15 tahun sampai dengan 64 tahun. Dengan umur kita dapat melihat kualitas dari kerja manusia. Dalam bidang pertanian tingkatan usia merupakan faktor penting, semakin muda usia maka kekuatan untuk menghasilkan produksi lebih maksimal atau lebih baik.

Pendidikan adalah usaha sadar dan terencana untuk mewujudkan suasana belajar dan proses pembelajaran agar peserta didik secara aktif mengambangkan potensi dirinya untuk memiliki kekuatan spiritual keagamaan, pengendalian diri, kepribadian, kecerdasan, akhlak mulia, serta keterampilan yang diperlukan dirinya, masyarakat, bangsa dan negara (Prihatiningtyas, 2015). Pendidikan 
membuka wawasan petani dalam menerima informasi dan teknologi dibidang pertanian mengingat semakin pesatnya perkembangan teknologi yang diharapakan dapat berdampak baik bagi peningkatan produksi, pendapatan dan akhirnya akan meningkatkan taraf hidup petani. Hasil penelitian menunjukan bahwa petani responden Dominan berpendidikan rendah $(38,16 \%)$ di Kecamatan Limbur Lubuk Mengkuang. Tingkat pendidikan petani dapat mempengaruhi pola pikir petani dalam penerapan ide-ide baru yang didapat. Petani yang berpendidikan, umumnya lebih mudah menerima inovasi dibanding dengan petani yang tidak berpendidikan walaupun ini tidak mutlak terjadi pada setiap petani. Hal ini sesuai dengan pendapat Awaluddin (2014), bahwa petani yang berpendidikan, lebih cepat mengerti dan dapat memahami penggunaan teknologi baru. Dengan demikian penerapan konsep dalam mengelola usahataninya lebih baik dan dapat tercapai sesuai dengan yang diharapkan. Selain itu penanggulangan masalah-masalah yang timbul dalam usahatani lebih mudah dikendalikan.

Pengalaman berusahatani dapat menjadi acuan bagi petani dalam menentukan keputusan usahataninya dengan belajar pada apa yang telah dilakukan selama ini. Pengalaman juga dapat menjadi pemacu minat petani dalam mengolah lahan pertaniannya karena dengan banyaknya pengalamanan yang mereka miliki maka akan ada banyak cara yang dapat mereka lakukan untuk meningkatkan produksi pertaniannya. Hasil penelitian menunjukan bahwa kisaran lama berusahatani petani responden dominan 6-10 tahun yaitu $(61.18 \%)$, Dengan demikian, petani dalam bertindak ia akan selalu berhati-hati mengingat banyaknya pengalaman yang telah ia dapatkan, apabila itu berhubungan dengan usahataninya. Hal ini sesuai dengan pendapat Krisnawati (2017) yang mengatakan bahwa pengalaman berusaha oleh seorang petani akan berbeda sesuai dengan situasi dan kondisi yang ada dengan lama petani yang telah menekuni suatu usaha pengelolaan usahatani tentu akan banyak pula pengalaman yang diperolehnya. Pengalaman dari apa yang dialami oleh seseorang akan menjadi suatu kebiasaan bila hal tersebut sering dilakukan. Lama berusaha dapat dianggap sebagai ukuran tingkat pengalaman dengan pengelolaan usahataninya tersebut.

Jumlah anggota keluarga sangat menentukan jumlah kebutuhan keluarga. Semakin banyak anggota keluarga berarti semakin banyak pula jumlah kebutuhan keluarga yang harus dipenuhi. Begitu pula sebaliknya, semakin sedikit anggota keluarga berarti semakin sedikit pula kebutuhan yang harus dipenuhi keluarga sehingga dalam keluarga yang jumlah anggotanya banyak akan diikuti oleh banyaknya kebutuhan yang harus dipenuhi. Semakin besar ukuran rumah tangga berarti semakin banyak anggota rumahtangga yang pada akhirnya akan semakin berat beban rumah tangga untuk memenuhi kebutuhan sehari-harinya. Hasil penelitian menunjukan bahwa jumlah tanggungan keluarga dari petani responden berkisar 1-8 orang. Jumlah tanggungan keluarga petani responden yang berdominan berkisar antara 1-4 (66,45\%) Besar kecilnya jumlah tanggungan keluarga akan menentukan perilaku petani dalam usahataninya. Banyak-nya jumlah tanggungan keluarga yang dimiliki dapat menjadi motivasi bagi petani untuk bekerja agar dapat memenuhi kebutuhan keluarganya dengan baik. Dilain pihak banyaknya jumlah tanggungan keluarga juga dapat menjadi alasan bagi wanita untuk turut serta bekerja dan memperoleh penghasilan.

Pada dasarnya luas lahan yang dikelola oleh petani responden sangat berpengaruh terhadap kegiatan usahataninya baik terhadap jenis komoditi maupun pada pola usahatani itu sendiri. Lahan garapan merupakan modal petani dalam berusahatani mengingat besar kecil pendapatan petani dipengaruhi oleh luas 
lahan garapannya. Pemanfaatan sumber daya lahan untuk pertanian harus dilakukan dengan memperhatikan karakteristik lahan, sehingga manfaat sumber daya lahan tersebut dapat dilestrikan. Hasil penelitian menunjukan bahwa luas lahan yang dimiliki petani responden dominan berkisar 1-2 $\mathrm{Ha}$ $(59,870 \%)$ Luas lahan rata-rata petani menunjukkan bahwa tingkat penguasaan lahan petani di Kecamatan Limbur Lubuk Mengkuang masih tergolong rendah. Hal ini sejalan dengan pendapat Kasim (2006) yang mengemukakan bahwa penguasaan lahan merupakan faktor yang turut menentukan tingkat pendapatan maupun kesejahteraan masyarakat. Oleh karena itu, besar atau kecilnya penguasaan lahan sangat menentukan besarnya pendapatan rumah tangga dan kemungkinan suatu rumah tangga berada dalam kemiskinan walaupun lahan tersebut pada umumnya diolah sendiri oleh buruh tani.

Umur ekonomis tanaman kelapa sawit yang dibudidayakan umumnya 25 tahun, Tetapi dewasa ini umur ekonomis tanaman bisa mencapai lebih dari 25 tahun. Pada umur diatas umur ekonomis tanaman sudah tinggi sehingga sulit di panen, tandanya sudah jarang sehingga secara perhitungan tidak ekonomis lagi.

Pengelompokan berdasarkan umur tanaman adalah sebagai berikut :

3-8 tahun : Muda

9-13 tahun : Remaja

$14-20$ tahun : Dewasa

$>20$ tahun : Dewasa

Pengelompokan berdasarkan masa berbuah :

TBM (Tanaman belum menghasilkan) : 0 -3 tahun.

TM ( Tanaman menghasilkan ) : > 3 tahun.

\section{Analisis Risiko Produksi}

Risiko usahatani kelapa sawit di Kecamatan Limbur Lubuk Mengkuang dari risiko produksi dan risiko pendapatan. Risiko ini dianalisis dengan koefisien variansi. Nilai koefisien variasi yang kecil menunjukkan variabilitas nilai rata-rata distribusi tersebut rendah. Hal ini menggambarkan risiko yang dihadapi kecil. Adapun analisis risiko produksi kelapa sawit di Kecamatan Limbur Lubuk Mengkuang.

\begin{tabular}{cccc} 
Tabel & $\begin{array}{c}\text { 3. Analisis } \\
\text { usahatani } \\
\text { Mengkuang }\end{array}$ & $\begin{array}{c}\text { Risiko } \\
\text { Limbur }\end{array}$ & $\begin{array}{c}\text { Produksi } \\
\text { Lubuk }\end{array}$ \\
\hline No & \multicolumn{2}{c}{ Uraian } & $\begin{array}{c}\text { Kelapa } \\
\text { sawit } \\
\text { (Ha/Bulan) }\end{array}$ \\
& & & 2.589 \\
1 & Rata-rata Produksi & 6,3219 \\
2 & (Kg/Ha) & 0,0024 \\
3 & $\begin{array}{l}\text { Standar Deviasi (Kg) } \\
\text { Koefisien Variasi } \\
\text { (Cv) }\end{array}$ \\
\hline
\end{tabular}

Sumber data: Data setelah diolah

Tabel 3 menunjukkan bahwa ratarata produksi petani kelapa sawit di Kecamatan Limbur Lubuk Mengkuang $2.589 \mathrm{Kg} / \mathrm{Ha} / \mathrm{Bulan}$. Dari perhitungan produksi tersebut, maka dapat diketahui besarnya standar deviasi kelapa sawit sebesar 6,3219 $\mathrm{Kg} / \mathrm{Ha} / \mathrm{Bulan}$. Koefisien variasi yang diperoleh berdasarkan perhitungan dengan membandingkan ratarata produksi dengan standar deviasi sebesar 0,0024. Nilai koefisien variasi kurang dari $0,5(0,0024<0,5)$. apabila CV $<0,5$ maka risiko produksi usahatani yang ditanggung petani semakin besar, Hasil analisis menunjukkan bahwa risiko produksi petani kelapa sawit di Kecamtan Limbur Lubuk Mengkuang tergolong risiko rendah. Menurut petani, risiko risiko yang hadapi seperti kurangnya pupuk bersubsidi masih dapat dikendalikan. Hal ini sesuai dengan pendapat salah satu petani yang mengatakan bahwa: "subsidi pupuk biasa lambat masuk, jadi beli pupuk ditempat lain" (15 Juni 2020), Bapak Bahtiar, 43 tahun

\section{Analisis Biaya Tetap}

Menurut Suratiya (2009) yang di maksud biaya tetap adalah biaya yang besar nya tidak dipengaruhi oleh besar nya produksi atau tidak habis satu kali 
produksi produksi biaya tetap yang terdapat pada usahatani kelapa sawit adalah penyusunan alat yang terdiri dari pompa semprot, parang, cangkul, gerobak , engrek, dodos dan pajak lahan. Pada penyusutan alat perhitungan dilakukan rumus penyusutan alat metode garis lurus, yaitu nilai awal di kurang nilai akhir dibagi dengan nilai ekonomis dikali umur pakai alat, dimna pada penggunaan cara perhitungan ini diasumsikan bahwa pada usia ekonomistertentu alat tidak memiliki usia untuk penentuan usia umur ekonomis didasarkan atas ketahannan alat dan penggunaan alat.

Di daerah penelitian sebagian lahan yang digunakan pada usahatani kelapa sawit adalah milik sendiri, tetepi karena usaha dianggap bersifat komersil. Untuk lebih jelas mengenai rincian tentang biaya tetap dapat di lihat dibawah Tabel 4 .

Tabel 4. Rata Rata Biaya Tetap Usaha Tani Kelapa Sawit Daerah Penelian

\begin{tabular}{clc}
\hline No & Biaya teatap & Total biaya \\
\hline 1 & Penyusutana & \\
& alat & 16.002 \\
& Parang & 11.868 \\
& Cangkul & 128.448 \\
& Gerobak & 169.258 \\
& Pompa semprot & 56.069 \\
& Engrek & 23.424 \\
2 & Dodos & 2.611 .842 \\
& sewa lahan & \\
\hline & JUMLAH & 3.015 .768
\end{tabular}

Sumber Data: data setelah diolah

Tabel 4 menunjukan bahwa di ketahui untuk biaya tetap usaha tani kelapa sawit meliputi biaya penyusutan alat dan sewa lahan. Rata rata sewa lahan yaitu sebesar $\mathrm{Rp}$ 2.611.842/Ha/Tahun dengan biaya penyusutan terkecil alat dodos yaitu Rp 23.424 . kecil nya penyusutan alat ini di karena lama pemakaian nya

\section{Analisis biaya variabel}

Untuk biaya variabel digunakan petani untuk membeli sarana produksi yang digunakan dalam melakukan usahatani kelapa sawit seperti pupuk,herbisida dan tenaga kerja. Besar nya rata - rata baiaya variabel yang digunakan petani kelapa sawit dapat dilihat pada tabel 5 di bawah ini

Tabel 5. Biaya rata rata variabel petani kelapa sawit

\begin{tabular}{|c|c|c|}
\hline No & Biaya variabel & $\begin{array}{l}\text { Total biaya } \\
\text { variable }\end{array}$ \\
\hline 1 & Biaya pupuk & 6.966 .315 \\
\hline 2 & Biaya herbisida & 1.214 .506 \\
\hline 3 & $\begin{array}{l}\text { Biaya tenaga } \\
\text { kerja }\end{array}$ & 45.665 .155 \\
\hline & Jumlah & 53.845 .978 \\
\hline
\end{tabular}

Sumber data: data setelah diolah

Tabel 5 menujukan bahwa biaya pupuk, biaya herbisida, tenaga kerja, biaya variabel yang terbesar pada usahatani kelapa sawit di Kecamatan Limbur Lubuk Mengkuang yaitu biaya tenaga kerja sebesar Rp 45.665.155 dan sedangkan biaya variabel terkecil yaitu biaya herbisida $\mathrm{Rp}$ 1.214.506. Untuk tenaga kerja upah dihitung perhari sedangkan untuk pemanen dan pengangkutan dihitung produksi yang di hasil kan (Ton) Selengkapnya Biaya total petani kelapa sawit di di Kecamatan Limbur Lubuk Mengkuang dapat di lihat di tabel 6 berikut

Tabel 6. Rata rata total biaya petani kelapa sawit

\begin{tabular}{clc}
\hline No & \multicolumn{1}{c}{ Uraian } & Total biaya \\
\hline 1 & Biaya variabel & 53.845 .978 \\
2 & Biaya tetap & 3.015 .768 \\
\hline & Jumlah & 56.861 .745
\end{tabular}

Sumber data : data setelah diolah

Tabel 6 menujukan bahwa biaya rata rata total yang di butuhkan untuk usahatani kelapa sawit adalah sebsar Rp 53.845.978 jika di lihat perbandingan antara biaya variabel dengan biaya tetap yang di peroleh dari penelitian ini memang terbukti dalam suatu usahatani kelapa sawit yang terbesar adalah biaya variabel sedangkan biaya terkecil adalah biaya tetap sebesar Rp. 3.015.768. 


\section{Analisis penerimaan}

Penerimaan adalah nilai uang yang diperoleh petani dari hasil jumlah produksi yang dihasil dengan satuan harga produksi. Sehingga diketahui bahwa besar kecilnya penerimaan sangat ditentukan oleh jumlah produksi tersebut. Untuk daerah penelitian harga jual rata rata kelapa sawit $\mathrm{Rp}$ $1.355 / \mathrm{Kg}$ harga jual kelapa sawit tergantung dengan usia tanaman. Rata rata penerimaa petani kelapa sawit sebesar Rp 111.045.571 dengan rata rata produksi 81.601(kg) besar produksi tiap luas lahan dengan jumlah tanaman yang sama tidak memberikan produsi yang sama pula.

\section{Analisis pendapatan}

Besar kecilnya pendapatan yang akan diterima tergantung kepada besar kecilnya penerimaan dan biaya yang akan dikeluarkan selama pelaksaan usahatani tersebut. Dimana jika penerimaan yang diperoleh tinggi bukan berarti pendapatan yang akan di peroleh juga besar jika ternyata biaya yang dikeluarkan kecil sedangkan jika penerimaan yang akan di peroleh rendah bukan berarti petani akan mengalami kerugian jika ternyata biaya yang dikeluarkan besar. Rata rata pendapatan yang diperoleh pada usaha tani kelapa sawit dapat dilihat di tabel dibawa ini.

Tabel 7. Rata rata pendapatan usahatani kelapa sawit

\begin{tabular}{llr}
\hline No & Uraian & Total \\
\hline 1 & Penerimaan & 111.045 .571 \\
2 & Biaya total & 56.861 .745 \\
\hline & Pendapataan & 54.183 .826 \\
\hline
\end{tabular}

Sumber data: data setelah diolah

Tabel 7 menujukan bahwa rata rata penerimaan yang diperoleh dari usahatani kelapa sawit yaitu sebesar $\mathrm{Rp}$ 111.045.571. dan ternyata pendapatan yang di peroleh sebesar Rp 54.183.826 sehingga terbukti bahwa penerimaan yang besar selalu diikuti dengan pendapatan yang di peroleh dari usaha tani kelapa sawit tesebut juga akan besar hal ini dikarenakan jumlah biaya total bisa ditekan.

\section{Analisis Risiko Pendapatan}

Risiko pendapatan dianalisis dengan koefisien variansi. Nilai koefisien variasi yang kecil menunjukkan variabilitas nilai rata-rata distribusi tersebut rendah. Hal ini menggambarkan risiko yang dihadapi kecil. Adapun analisis risiko pendapatan petani kelapa sawit di Kecamatan Limbur Lubuk Mengkuang, dapat dilihat pada Tabel 8 .

Tabel 8. Analisis risiko pendapatan usahtani Kecamatan Limbur Lubuk Mengkuang Kabupaten Bungo

\begin{tabular}{clrl}
\hline No & \multicolumn{2}{c}{ Uraian } & $\begin{array}{l}\text { Kelapa sawit } \\
\text { (Ha/Bulan) }\end{array}$ \\
\hline 1 & Rata & Rata & 1.708 .122 \\
2 & Pendapatan & & $1.066,7798$ \\
3 & $(\mathrm{Rp} / \mathrm{Kg})$ & 0,00062 \\
& $\begin{array}{l}\text { Standar } \quad \text { Deviasi } \\
\text { (Kg) }\end{array}$ & \\
& Koefisien & Variasi \\
& & \\
& $(\mathrm{Cv})$ & & \\
\hline
\end{tabular}

Sumber data: Data setelah diolah

Tabel 8 menunjukkan bahwa ratarata pendapatan petani kelapa sawit di Kecamtan Limbur Lubuk Mengkuang Rp 1.708.122 /Ha/Bulan. Dari perhitungan analisis pendapatan tersebut, maka dapat diketahui besarnya standar deviasi kelapa sawit sebesar 1.066,7798/Ha/ Bulan. Koefisien variasi yang diperoleh berdasarkan perhitungan dengan membandingkan rata-rata pendapatan dengan standar deviasi sebesar 0,00062. Nilai koefisien variasi lebih kecil dari 0,5 $(0,00062<0,5)$. Hal ini menunjukkan bahwa apabila $\mathrm{CV}<0,5$ maka risiko pendapatan usahatani yang ditanggung petani semakin rendah. Hasil analisis menunjukkan bahwa risiko pendapatan petani kelapa sawit di Kecamatan Limbur Lubuk Mengkuang risiko rendah. Menurut petani, risiko risiko yang hadapi seperti biaya tenaga kerja yang dapat berubahubah dan penjualan TBS ke pabrik masih 
dapat dikendalikan dengan tetap memperhatikan biaya pengeluaran usahatani dan meningkatkan produktivitas. Hal ini sesuai dengan pendapat salah satu petani yang mengatakan bahwa: "mahal ongkos angkut TBS nya krn agak jauh ke pabrik" (20 Juni 2020, Bapak Amran, 42 tahun)

Menurut Fauziyah (2011) struktur pendapatan yang dimiliki oleh petani akan mempengaruhi perilaku petani dalam menghadapi risiko. Jika pendapatan yang dimiliki oleh petani cukup besar maka mereka dapat melakukan berbagai strategi untuk mengurangi risiko yang hadapi begitu juga sebaliknya. Pendapatan yang diterima petani kelapa sawit di Kecamatan Limbur Lubuk Mengkuang dapat dikatakan cukup menguntungkan

\section{Upaya Memitigasi Risiko}

\section{A. Risiko Produksi}

permasalahan yang paling sering dihadapi oleh petani yaitu permasalahan mengenai iklim dan pupuk bersubsidi. Petani di Kecamatan Limbur Lubuk Mengkuang mengatakan bahwa dengan adanya iklim yang tidak menentu merupakan risiko utama. Curah hujan yang terus menerus menyebabkan berbagai macam hama dan penyakit yang menyerang tanaman serta jalan rusak menuju lokasi tempat pengumpulan buah (TPH) kelapa sawit petani.

. Untuk mengatasi permasalahan hama dan penyakit sebaiknya petani melakukan pengamatan secara langsung pada tanaman.

1. Apabila terjadi tanda-tanda serangan hama dan penyakit, maka petani segera mempersiapkan obat-obatan yang sesuai untuk mengatasi hama dan penyakit tersebut.

2. Untuk permasalahan pupuk bersubsidi, sebaiknya ketua kelompok petani menyusun recana definitif kebutuhan kelompok (RDKK) dengan benar dengan data petani yang ada agar pupuk bersubsidi bisa sampai dengan petani
3. Membuat jalan produksi swadaya kerja sama antara kelompok tani dan pemerintah

4. Sebaiknya Rencana Definitif kebutuhan Kelompok (RDKK) di awasi dari atas sampai bawa agar tidak pihak yang menyalah gunakan pupuk bersubsidi.

\section{B. Risiko Pendapatan}

Risiko yang sering dihadapi petani dalam pemasukan buah kelapa sawit ke pabrik perusahaan. saat proses pemasukan buah banyak mobil truk yang antri sangat lama di luar pabrik dan menyebabkan standar mutu buah tandan buah segar (TBS) kurang sesuai dengan standar mutu buah yang telah disepakati oleh perusahaan dan petani. Salah satu penyebab antrinya mobil truk pengangkut buah yaitu karena pemasukan buah petani ke pabrik tidak sesuai dengan jadwal yang telah diberikan perusahaan sehingga harus melalui antrian dengan mobil angkut buah petani-petani yang lain. Untuk mengatasi masalah tersebut,

1. sebaiknya petani lebih memperhatikan jadwal panen dan pengangkutan buah agar pemasukan buah ke pabrik dapat dilakukan tepat waktu.

2. Selain itu, petani sebaiknya memperkuat kelembagaan sehingga ketua lembaga mampu menyampaikan permasalahan yang dialami kepada pihak indutri pabrik kelapa sawit.

3. Masalah harga tandan buah segar (TBS) kelapa sawit ini telah ditentukan oleh pusat. Penetapan harga TBS dibuat sesuai dengan ketentuan di dalam SK Menteri Kehutanan dan Perkebunan No. 627 Tahun 1998. Harga TBS ditentukan oleh tim yang terdiri dari dinas perkebunan, wakil perusahaan inti, dan wakil petani. Untuk mendapatkan harga yang maksimal, upaya yang perlu dilakukan yaitu petani sebaiknya mampu memperhatikan kualitas dan mutu TBS agar dapat memperoleh hasil penjualan yang tinggi. 
Kesimpulan Dan Saran

\section{Kesimpulan}

Berdasarkan uraian pada hasil penelitian, maka dapat ditarik kesimpulan sebagai berikut

1. Risiko produksi diperoleh nilai Koefisien Variasi (CV) sebesar 0,0024 Artinya, apabila $\mathrm{CV}<0,5$ maka risiko produksi usahatani yang di hadapi petani Kecamatan Limbur Lubuk Mengkuang rendah.

2. Risiko pendapatan diperoleh nilai Koefisien Variasi (CV) sebesar 0,00062. Artinya, apabila CV $<0,5$ maka risiko pendapat usahatani yang di hadapi petani Kecamatan Limbur Lubuk Mengkuang rendah.

3. Upaya Memitigasi Risiko Produksi Dan Pendapatan Di Kecamtan Limbur Lubuk Mengkuang adalah sebagai berikut

a. Risiko produksi

a) mempersiapkan obat-obatan yang sesuai untuk mengatasi hama dan penyakit tersebut.

b) Untuk permasalahan pupuk bersubsidi, sebaiknya ketua kelompok petani menyusun RDKK (rencana definitif kebutuhan kelompok) dengan sesuai dengan data petani yang ada.

c) Membuat jalan produksi swadaya kerja sama antara kelompok tani dan pemerintah .

d) Sebaiknya RDKK (rencana definitif kebutuhan kelompok) di awasi dari atas sampai bawa agar tidak ada pihak yang menyalah gunakan pupuk bersubsidi.

b. Risiko pendapatan

a) petani lebih memperhatikan jadwal panen dan pengangkutan buah agar pemasukan buah ke pabrik dapat dilakukan tepat waktu.

b) petani memperkuat kelembagaan sehingga ketua lembaga

mampu menyampaikan permasalahan yang dialami kepada pihak indutri pabrik kelapa sawit.

c) Petani memperhatikan kualitas dan mutu TBS agar dapat memperoleh hasil penjualan yang tinggi.

\section{Saran}

Berdasarkan hasil penelitian yang telah dilakukan, maka disarankan beberapa hal sebagai berikut :

1. Bagi petani, hendaknya mampu memperhatikan sumber daya peralatan yang digunakan dalam berusahatani yaitu dengan menambah peralatan yang masih kurang sehingga mampu meningkatkan produkstivitas dalam usahatani kelapa sawit.

2. Bagi petani, sebaiknya memperhatikan penyediaan pasar untuk penjualan hasil produksi kelapa sawit (Tandan Buah Segar) yaitu perusahaan yang bermitra dengan memperkuat solidaritas kelembagaan petani sehingga petani mampu menjual hasil produksinya tepat waktu.

3. Bagi pemerintah, sebaiknya memperhatikan penyediaan sarana produksi terutama pupuk maupun permodalan berdasarkan dengan kebutuhan petani agar dapat mendukung kegiatan usahatani kelapa sawit yang dilakukan petani di Kecamatan Limbur Lubuk Mengkuang.

\section{Daftar Pustaka}

Arikunto, Suharsimi. 2006. Metodelogi penelitian. Yogyakarta: Bina Aksara

Awaluddin. 2014. Kajian Model Pemberdayaan Petani Padi melalui Penggunaan Tiga Media Komunikasi di Kabupaten Bima. https://habitat.ub.ac.id/index.php/ habitat/article/download/155/177. Diakses pada tanggal 25 
September 2017 pukul 23.56 WITA. Makassar..

Badan pusat statistik Provinsi jambi 20152019

Badan Pusat Statistik kabupten bungo. 2019

Bungo dalam angka 2019.Statistik Kabupaten Bungo. .

Fauziyah, E. 2011. Manajemen Risiko Usahatani Padi Sebagai Salah Satu Upaya dalam Mewujudkan Ketahanan Rumah Tangga Petani. http://pertanian.trunojoyo.ac.id/se mnas/wp-content/uploads/

Manajemen-Risiko-Pada-

Usahatani-Padi-Sebagai-Salah Satu-Upaya-

Fikriman, F., \& Herdiansyah, A. (2017). Faktor-faktor yang Mempengaruhi Produktivitas Tenaga Kerja Buruh Panen Buah Kelapa Sawit (studi Kasus pada Divisi I PT. Megasawindo Perkasa Ikecamatan Pelepat Kabupaten Bungo). JAS (Jurnal Agri Sains), 1(1).

Fikriman, F. (2017). Tranformasi Pertanian dan Pembangunan Pedesaan. JAS (Jurnal Agri Sains), 1(2).

Kantor pertanian,2019 Kematan Limbur Lubuk Mengkuang. Kabupaten Bungo. Provinsi Jambi

Kementerian Pertanian. 2016. Basis Data Pertanian.

https://aplikasi2.pertanian.

go.id/bdsp2/id/lokasi. Diakses pada tanggal 9 Februari 2017 pukul 21.39 WITA. Makassar.

Kementrian Pertanaian 2015-2019 Buku Publikasi Statistik

Prihatiningtyas, Eko. 2015. Analisis

Faktor-Faktor Yang Mempengaruhi Struktur Modal Pada Perusahaan Otomotif Yang Terdaftar Di Bursa Efek Indonesia Tahun 2008-2013. Skripsi, Fakultas Ekonomi \& Bisnis.
Soekartawi, Rusmiadi, dan E. Damaijati. 1993. Risiko dan Ketidakpastian dalam Agribisnis (Teori dan Aplikasi). Raja Grafindo Persada. Jakarta.

Suharyanto, dkk. 2016. Analisis Risiko Produksi Usahatani Padi di Provinsi Bali. https://www.journal.umy.ac.id/ind ex.php/ag/article/ view/1117/1195. Diakses pada tanggal 26 April 2017 pukul 20.51 WITA. Makassar.

Sukamto. 2008. 58 Kiat Meningkatkan Produktivitas dan Mutu Kelapa Sawit. Penebar Swadaya. Jakarta. 